\title{
Payment of Tax and Labor Wages Debt When the Company Experiences Bankruptcy in Indonesia
}

\author{
Rahayu Hartini \\ Faculty of Law of Muhammadiyah Malang University, Jl. Raya Tlogomas Number 246, Malang, Indonesia
}

\begin{abstract}
The Bankruptcy Decision is both instantaneous and constitutive that it excludes circumstances and creates a new legal state. In the judge's verdict on bankruptcy there are three essentials: the statement that the debtor is bankrupt, the appointment of a Designated Judge of the Judge of the Court and the Curator. Substantively UUK and PKPU still have some weaknesses, as well as in practice. In this study the authors focus on the problem of "Which should take precedence between tax debt with the wages of workers in the case of companies experiencing bankruptcy in Indonesia?". How is the scale of payments prioritized to the separatist, preferred and concurrent creditor in practice is still often found the existence of legal uncertainty.
\end{abstract}

Keywords:debt payments, taxes, workers' wages, bankruptcy, creditors.

DOI: $10.7176 / \mathrm{JLPG} / 92-22$

Publication date: December $31^{\text {st }} 2019$

\section{A. INTRODUCTION}

The bankruptcy arrangements in Indonesia were initially based on the provisions of Fereordening failissement which comes from the Dutch inheritance rule that was valid until 1998. Subsequently in 1998, the Government Regulation in Lieu of Law (Perpu) no. 1 of 1998 was subsequently upgraded to Law No. 4 of 1998 on Bankruptcy and PKPU. In the process, there are some weaknesses which leads to improvement to Law No. 37 of 2004.

Bankruptcy is a common confiscation of all the wealth of bankrupt debtors whose management and ordering is done by the Curator under the supervision of the Supervisory Judge. The conditions to be declared bankrupt in principle is very simple (Article 2 paragraph (1) UUK and PKPU, namely: 1) Debitor who has two or more creditors, 2). No payment for at least one debt has fallen and can be collected, 3). At his sole request or at the request of one or more of his creditors.

In practice, a lot of unequal judges' understanding of the Commercial Court is found in this regard. Another problem related to the implementation of separatist rights when it is attributed to tax collecting and collecting rights, there is often a legal uncertainty in its application so that what is earlier to be paid between the tax debt and the wage of workers becomes unclear. This happens because of the two provisions of the Conflicting Laws namely the Tax Law and the Law on Manpower (Hartini, 2017c)

Some previous research that has been done by the author related to bankruptcy issues, among others, is about; Authority of Commercial Court in Settlement of Bankruptcy Arbitration Case (Case Study of Bankruptcy Decision), Model of Bankruptcy Case Settlement With Arbitration Clause (Sebuah Resolusi Konflik Dualisme Hukum Kepailitan Dan Arbitrase Di Indonesia) (Hartini, 2008), Bankruptcy Law of Indonesia Viewed From the aspects of Epistemologi And Aksiologi (Hartini, 2009), UUK and PKPU No 37 Th 2004 Override the Entitlement of Sunt Servanda Pact In Resolving Bankruptcy Dispute (Hartini, 2015b), Legal Protection Against the Defaulted Airlines (Hartini, 2014b) , Legal Status Of Bank Guarantee On Behalf Of Third Parties In Bankruptcy Perspective.

In addition, some of the author's thoughts have been submitted in various scientific forums at national and international levels in the form of papers and proceedings related to bankruptcy research, namely: Point Link Bankruptcy and Arbitrage in Facing MEA (Hartini, 2015a) (national). Furthermore, in international conference: Reconstruction of the Bankruptcy Law-Based Arbitration Clause "Pacta Sunt Servanda" In Dispute Resolution Bankruptcy Law Reform Efforts For The Fair (Hartini, 2014c), on the International Conference Gouverment 2014 (ICG 2014), Legal Aspect of Damages related Financial Management Limited SOE State (Hartini, 2014a), Bankruptcy and Suspension of Payment Law: Lesson from Indonesia Court Decision (Hartini, 2017).

While another research has been done by other researchers, among others by: Lili Naili Hidayah on: Insolvency Indicators as Conditions of Bankruptcy Under Indonesian Bankruptcy Law (Hidayah, 2016), Bankruptcy of Joint Operation And The Responsibilities The Member of Joint Operation (Zukhruffiyah Rizqi Adinda, 2018), Cross-border bankruptcy in the Perspective of International Law And Comparison With National Instruments In Some Countries (Hardjaloka, 2015), and by Paul Herdianto Manurung regarding the Right of Preceding Debt Collection for Taxpayers which are Declared as Bankrupt (Manurung, n.d.), The Authority of the Public Prosecutor as Applicant Bankrupt For State Interest on Tax Debt The Subject of Law Of 
ASEAN Non-Indonesian Country After the Entry into Force of AEC (Arjaya, 2014).

The difference of this research with some previous authors research with other authors is that in this study is more focus to review bankruptcy when it is associated with the existence of creditors consisting of taxes and workers / laborers. The legal issues are: How is the payment between tax debt and wages of workers or laborers in bankruptcy after the decision of the Constitutional Court Year 2013? So, in this case, it must be known the position between tax debts with wage laborers as creditor in bankruptcy so that it will be known the sequence in its payment when happened bankrupt.

\section{B. METHOD}

This type of research is a normative juridical research (Marzuki, 2009), because the matter which is studied is the philosophy of the norms related to the principal issues studied, namely norms in the field of Bankruptcy Law, Labor Law and Tax Law, especially related to the tax debt also concerns the aspect of justice and legal certainty. By using the approach of the law (statute approach), conceptual (conceptual approach) (Marzuki, 2009).

By using primary and secondary legal materials, which are primary: legislation in the field of Bankruptcy and PKPU, Labor Law and Taxation Code (KUP). Secondary, obtained from textbooks/literatures, journals of law and the results of previous studies that discussed related to the issue of law in this study. The primary and secondary legal materials that have been collected through the inventory are then grouped and studied by statute approach and the conceptual to obtain basic knowledge of the legal material. The legal materials are prescriptive. The analysis is done by content analysis by comparing with the doctrine, theory and principle of law presented by experts, based on reasoning or logic in legal argumentation. Analysis is done to find the truth.

\section{RESULTS}

\section{Due to Bankruptcy against Agreement between Debtor and Bankrupt Worker.}

Due to the general bankruptcy statement according to Sutan Remy Sjahdeini is 1 . The wealth of bankrupt debtors who enter the property of bankruptcy is a public confiscation of the property of the declared bankrupt. According to Article 21 of the UUK, bankruptcy covers the entire wealth of the debtor at the time of the declaration of bankruptcy declaration is pronounced as well as everything earned during bankruptcy. 2 . Bankruptcy is solely about the property of bankruptcy and is not about the personal debtor of bankruptcy. For example, a person may remain married even if he has been declared bankrupt. 3. The debtor by law loses his right to control and administer the property which is included in the bankruptcy property, from the date of the decision of the bankruptcy declaration is pronounced (Article 24 UUK). 4. Bankruptcy assets are taken care of and controlled by the curator for the benefit of all creditors and debtors and supervisory judges lead and control the execution of bankruptcy proceedings. 5. Claims concerning rights or obligations concerning bankruptcy property shall be filed by or against the curator (Article 26 paragraph (1) of the UUK) (Manurung, n.d.).

In general, the consequences of bankruptcy can be said to be both immediate and constitutive, ie to eliminate the situation and create a new legal state. In the judge's verdict on bankruptcy there are 3 essentials (Hartini, 2017b): Statement that the debtor is bankrupt, Appointment of a Designated Judge of the Judge of the Court, and the Curator.

In particular, in the case of an employment agreement, the worker working on the Debtor may terminate the employment relationship, and the Curator may terminate it by observing the period of time in accordance with the applicable agreement or the provisions of the law, with the understanding that the employment relationship may be terminated by notice at least 45 days in advance (Hartini, 2017b). The provisions concerning termination of employment, the curator shall be guided by the laws and regulations in the field of manpower (Article 39 paragraph (1) UUK and PKPU). Since the date of the decision of bankruptcy statement in pronounced, the wages owed before and after the declaration of bankruptcy declaration is said to be the debt of bankruptcy property. Wages are the right of workers to be received and expressed in the form of money in return of the employer to the worker for a work on services which has been or will be done, fixed and paid under a work agreement, agreement or law, including allowances for workers and family (Article 39 Paragraph (2) of UUK and PKPU and its explanation).

\section{Payments of Taxes and Wages of Workers in Bankruptcy}

According to Article 21 of the General Taxation Laws Act (UU KUP), the state has the right to precede the tax debt on the goods of the Taxpayer. The provisions of this article shall determine the status of the state as the preferred creditor who has the right to precede the goods of the Taxpayer to be sold except to the cost of the case solely by a 
punishment for auctioning of a moving good and / or immovable property. Payments to other creditors are settled after the tax debt has been paid.

Whereas in Article 95 Paragraph (4) of Law no. 13 of 2003 on the Law on Customs and Excise also regulates the right of preempting for wages and the rights of workers against other debts in the event of bankruptcy. Therefore, based on these provisions, both the KUP Law and the Manpower Act give priority to the object to obtain a reference / right of pre-emption.

In such a case, which should take precedence between the two laws?. According to UU KUP certainly prioritize that the tax debt becomes the most priority while according to the Labor Law prioritize the payment of wages of workers.

\section{a. Position of Tax Debt in Bankruptcy}

The position of tax debt is different from other debts. Tax liability arises from the Act and does not arise as a result of legal relations among citizens. Tax liability can be imposed because it involves the obligation of citizens to the state. However, the wider understanding of citizens is that including all foreign individuals who live in the territory of Indonesia for more than 183 days and earn income from business entrenched in Indonesia (see Article 2 Ayat (4) Law No 7 Year 1983 and Law No. 36 Year 2008 (Indonesia, 2008).

The position of tax debt in the Civil Code has placed the tax debt to take precedence over other creditors as regulated in Articles 1134 and 1137 Civil Code. Based on Article 1134 and 1137 Civil Code, the position of tax debt as a holder of privileges with preceding right refers to the regulation in special law, namely the Law of KUP.

Judging from the broad sense of debt in UUK-PKPU, debt is a liability that can arise from agreements or from contracts that are born under the law. Debts or tax bills must be settled by the taxpayer or the taxpayer. Taxpayers in exercising their rights and obligations in accordance with the tax laws and regulations may be represented among others by the Board. Bodies that have been declared bankrupt then the curator is tasked to make arrangements and order debtor bankruptcy property. The state has a prior right to the tax debt on all debtor's possessions. The preceding rights are stipulated in Article 21 paragraph (1) of the KUP Law, which reads: "The state has the preceding right to tax debt on the goods of the Taxpayer". The preceding right in Article 21 Paragraph (1) of this KUP Law also stipulates that the state as the preferred creditor is deemed to have prior rights over the property of the taxpayer to be auctioned publicly. Payments to other creditors are settled after the tax debt is paid. Provisions on prior rights include tax principal, administrative sanctions in the form of interest, penalties, increases, and tax collection fees (Fernandez, 2012).

The provisions of Article 21 of the KUP Law are in line with Article 1137 Civil Code which regulates the State Rights as follows: "The right of the state treasury, auction office and other public bodies established by the government, to take precedence, orderly exercise of such rights, and that right, regulated in various special laws regarding it ".

The special law regulating the matters referred to in Article 1137 of the Civil Code is one of the special KUP Law of Article 21. Therefore, by referring to the above provisions on the right of the state to the payment of tax debt shall be placed as the holder of the right of the first position, followed by the separatist creditor (holders of mortgages, mortgage, fiduciary, mortgages).

\section{b. Position of Labor Wages in Bankruptcy}

The definition of wages as set forth in the Elucidation of Article 39 of UUK-PKPU is the right of workers received and expressed in the form of money in return of the employer to the worker for a work or service which has been or will be done, determined and paid according to an employment agreement, or legislation, including benefits for workers and families. Since the date of decision of the bankruptcy statement is pronounced, the wages owed before and after the declaration of bankruptcy declaration is pronounced is a debt of bankruptcy. The provision is contained in Article 39 paragraph (2) UUK-PKPU. A bankrupt company may not be able to pay its creditors so that it can also have wage debt to the employee.

In the Manpower Act also regulates the preceding right of Article 95 Paragraph (4) and its Elucidation has regulated the position of debt of wages of employees or employees of bankrupt debtors as follows: "In the case of a company declared bankrupt or liquidated under applicable laws and regulations, and other rights of the worker / laborer shall be the debt of the payment ". Under this provision, the position of the worker / laborer shall be the creditor, then in the event of bankruptcy, the labor rights shall be equal to the other creditors. The problem is the position of the worker as the creditor in which classification (separatist, preferred, or concurrent creditors) as this will determine the order of priority of payment.

Article 1134 of the Civil Code describes the following privileges: "Privilege is a right granted by law to a creditor that causes him to be higher than the other, solely on the nature of the receivable. Pawn and hypothec are higher than privileges, unless the law expressly defines the reverse".

Regarding Privileges is further stipulated in Article 1149 of the Civil Code: "The privilege of all 
movable and immovable objects in general: a) b). Worker's salary over the past year and wages paid in the current year, along with the money to be paid by the employer either to the workers or to the workers' families".

Article 95 Paragraph (4) of the KT Law shall place the wage of workers in the position of the Preferential Lender, as it has the privilege granted by the Act. From the provisions of Article 1134 of the Civil Code, it is explained that the creditors of mortgage lenders and mortgages have a higher level than the privileged creditor, unless the law expressly regulates otherwise. Thus, if the KT Law wishes to exclude that privilege position is higher than a mortgage and mortgage (Separatist Creditor), the KT Law must state specifically that its rate is higher than Separate Creditors are not contained in the Law on KT. This resulted in the wage of his / her employee under his Separatist Creditor. The provision of Article 95 Paragraph (4) of the Law on Right and Regulatory Body does require companies that have bankruptcy to comply with the fulfillment of workers' rights such as severance pay and other rights. As a result, in practice, the notion of the word "precedence of payment" is placed after the repayment of the rights of the state and its separatist creditors. This problem is often the cause of debate in case of bankruptcy (Fauzi, 2017) (Hartini, 2017c)

\section{c. Decision of Constitutional Court No. 67/PUU-XI/2013}

Decision of the Constitutional Court No. 67/PUU-XI/2013 is issued because there is a Judicial Review (JR) filed by Ir. Otto Geo Diwara Purba, et al. On January 30, 2014, the Constitutional Court has adjudicated the application of the JR with the following rulings: 1). Article 95 paragraph (4) of Law Number 13 Year 2003 on Manpower (State Gazette of the Republic of Indonesia Year 2003, Number 39, Supplement to the State Gazette of the Republic Indonesia Number 4279) is inconsistent with the 1945 Constitution of the State of the Republic of Indonesia as long as it is not interpreted:

"Payment of indebted wages of workers/laborers shall take precedence over all types of creditors including on the bills of separatist creditors, state rights bills, auction offices, and public bodies established by the Government, while other payments of workers' rights come to all bills including state bills, auction offices, and public bodies established by the Government, except for bills from separatist lenders";

2). Article 95 Paragraph (4) of Law Number 13 Year 2003 concerning Manpower (State Gazette of the Republic of Indonesia Year 2003, Number 39, Supplement to State Gazette of the Republic of Indonesia Number 4279) has no binding legal force as long as it is not interpreted: "the payment of indebted wages of workers/laborers shall take precedence over all types of creditors, including on the bills of separatist creditors, state rights bills, auction offices, and public bodies established by the Government, whereas other payments of workers' rights shall take precedence over all invoices including state bills, auction offices, and public bodies established by the Government, except bills of separatist creditors";

Based on the decision of the Constitutional Court, it is clear that if there is bankruptcy, the right to precede the tax debt is not valid if it meets the wages of workers/workers and other workers' rights. This is somewhat different from separatist creditors if there is a wage payment for workers/laborers then the separatist creditor succumbs but not to the payment of the rights of other workers.

The consideration of the Panel of Judges to decide this is the wage of workers/laborers constitutionally based on Article 28 D Paragraph (2) of the 1945 Constitution is a constitutional right which is therefore also a constitutional right to obtain fair and decent treatment in the employment relationship. As for the obligations / bills of the state, it is reasonable to be ranked after wages and workers' rights (such as severance pay, gratuity and compensation pay and so forth). This is because countries have other sources of financing whereas for workers, wages are the only source of survival for themselves and their families. So with the decision of the Constitutional Court which places the wages of workers as the first priority of payment in the event of bankruptcy, the next priority is the state's right namely tax debt.

\section{E. CONCLUSION}

Based on the discussion of research results concluded that: Payment of Tax Debt and wages of workers in bankruptcy is seen based on the existence of the position or the order based on is: 1). Position of Taxable Debt Under Bankruptcy, pursuant to Article 21 of this KUP Law is in line with Article 1137 of the Civil Code, that the tax debt should take precedence over the payment. 2). Status of Labor Wage In Section, according to Manpower Law Article 95 Paragraph (4) and its Elucidation are contradictory to Article 1137 Civil Code, because according to the Law of KT that Laborer's wage must be paid first while in UUK and PKPU which must be paid first is tax debt because separatist lender. The content of this KT Law is contradictory to the KUP Law. 3). Decision of the Constitutional Court No.67/ PUU-XI/2013, according to the consideration of the Constitutional Court in the event of bankruptcy, the right of prior to the tax debt is not valid if it meets with the wages of workers/laborers and other workers' rights. So with the decision of the Constitutional Court to put the wages of workers as the first priority of payment in the event of bankruptcy, the next priority is the right of the country i.e. tax debt. This is somewhat different from the separatist Creditor where if there is a payment of the wages of the worker/laborer then the 
separatist creditor succumbs but not to the payment of the rights of other workers.

\section{F. References}

Arjaya, B. G. M. W. (2014). Wewenang Kejaksaan Sebagai Pemohon Pailit Untuk Kepentingan Negara Terhadap Utang Pajak Subyek Hukum Dari Negara ASEAN Non Indonesia Pasca Berlakunya AEC. Jurnal Rechts Vinding , Media Pembinaan Hukum Nasional, 3, Nomor 2(10), 197-213.

Dedy Tri HartonoNating, I. (2016). Perlindungan Hukum Kreditor Berdasarkan Undang-undang

Fauzi, W. (2017). Arrangement of Investment-Based Insurance after the Enactment of Law No 40 Year 2014 on Insurance. Journal of Law, Policy and Globalization, 65(40), 128-133. Retrieved from www.iiste.org

Fernandez. (2012). Tinjauan yuridis hak mendahulu pelunasan utang pajak atas harta pailit dan penyelesaian utang pajak dalam kepailitan skripsi. Universitas Indonesia. Retrieved from http://lib.ui.ac.id/file?file=digital/20289052-S1197-Fernandez.pdf

Hardjaloka, L. (2015). Kepailitan Lintas Batas Perspektif Hukum Internasional Dan Perbandingannya Dengan Instrumen Nasional Di Beberapa Negara. Yuridika, 30(3), 385. https://doi.org/10.20473/ydk.v30i3.1952

Hartini, R. (2008). Model Penyelesaian Kasusu Kepailitan Dengan Klausul Arbitrase (Sebuah Resolusi Konflik Dualisme Hukum Kepailitan Dan Arbitrase di Indonesia). Jurnal Ilmu Hukum Amanna Gappa, 16, Nomor, $1-25$.

Hartini, R. (2009). Hukum Kepailitan Indonesia Ditinjau Dari Aspek Epistemologi dan Aksiologi. Yustika, Media Hukum Dan Keadilan, FH Ubaya, 12, No.2, 131-236.

Hartini, R. (2014a). Legal Aspect of Damages Related Financial Management Limited SOES State. Penang, Malaysia.

Hartini, R. (2014b). Perlindungan Hukum Terhadap Maskapai Penerbangan Yang Dinyatakan Pailit. Hukum Bisnis, 33- No 1(Kepailitan: Implementasi Dan Implikasinya), 35-47.

Hartini, R. (2014c). Reconstruction of the Bankruptcy Law-Based Arbitration Clause "Pacta Sunt Servand" In Dispute Resolution Bankruptcy Law Reform Efforts For The Fair (No. 11). Malaysia. Retrieved from https://law.nus.edu.sg/asli/index.aspx

Hartini, R. (2015a). Titik Taut Pailit Dan Arbitrase Dalam Menghadapi MEA. Jambi.

Hartini, R. (2015b). UUK dan PKPU No 37 Tahun 2004 Mengesampingkan Berlakunya Asas Pacta Sunt Servanda Dalam Penyelesaian Sengketa Kepailitan. Yustisia, 4, Nomor 2(37), 292-309. Retrieved from https://jurnal.uns.ac.id/yustisia

Hartini, R. (2017a). Bankruptcy and Suspension of Payment Law : Lesson from Indonesia Court Decision Rahayu Hartini Universitas Muhammadiyah Malang Email: rahayuhartini@yahoo.co.id Abstract (pp. 573-581). Cambodia.

Hartini, R. (2017b). Hukum Kepailitan, Eidsi Revisi (Cetakan ke). Malang: UMM Press.

Hartini, R. (2017c). Legal Status of Bank Guarantee on Behalf of Third Parties in. Yustisia, 6, Nomor 1(1), 190198. Retrieved from https://jurnal.uns.ac.id/yustisia

Hidayah, L. N. (2016). Jurnal Ilmu Hukum, Volume 6, Nomor 2, Oktober, 2015. Jurnal Ilmu Hukum, 7, Nomor 1, 134-144. Retrieved from https://repository.unja.ac.id/613/1/8. Lili Naili.pdf

Indonesia, R. (2008). Undang-Undang Republik Indonesia Nomor 36 Tahun 2008 Tentang Perubahan Keempat atas Undang-Undang Nomor 7 tahun 1983 Pajak Penghasilan, Lembaran Negara Republik Indonesia Tahun 2008 Nomo.

Manurung, P. H. (n.d.). Hak mendahului tagihan utang pajak untuk wajib pajak yang dinyatakan pailit paulus herdianto manurung.

Marzuki, P. M. (2009). Penelitian Hukum (Revisi). Jakarta: Kencana_Prenada Media.

Syahdeini, S. R. (2002). Hukum Kepailitan. 